\title{
Gastroesophageal reflux (Clinical case)
}

\author{
Refluxo gastroesofágico (Caso clínico)
}

Ariana Saraiva ${ }^{1}$, António Raposo ${ }^{2 *}$

${ }^{1}$ Pharmacy Faculty, University of Coimbra, Azinhaga de Santa Comba, 3000-548 Coimbra, Portugal.; ${ }^{2}$ CBIOS (Research Center for Biosciences and Health Technologies), Universidade Lusófona de Humanidades e Tecnologias, Campo

Grande 376, 1749-024 Lisboa, Portugal

* Corresponding author: antonio.raposo@ulusofona.pt

Received / Recebido: 17/04/2019 Accepted / Aceite: 30/09/2019

Electronic Edition: www.alies.pt

A 53-year-old businesswoman, who has constant heartburn complaints, especially after meals. She was sent to the Nutrition Consultation by the general practitioner for gastroesophageal reflux, who medicated her with the antacid Maalox.

\section{Anthropometric evaluation}

Weight: $76.7 \mathrm{~kg}$

Height: $160 \mathrm{~cm}$

BMI: $29.96 \mathrm{~kg} / \mathrm{m} 2$

Waist circumference: $86 \mathrm{~cm}$

Assessment of body composition (TANITA BC-545N) Body fat: $42.8 \%$

Total body water: $42 \%$

\section{Analytical Parameters:}

\section{Hematology}

Leukocytes: $5.6 \times 10^{9} / \mathrm{L}(4.0-10.0)$

Erythrocytes: $4.9 \times 10^{12} / \mathrm{L}(3.9-5.2)$

Hemoglobin: 15.4 g/dL (12.0-16.0)

Hematocrit: $44.4 \%$ (34.7-46.0)

Glycated hemoglobin (A1C): 4.7\% (4.0-6.0)

\section{Biochemistry}

Glucose: $75 \mathrm{mg} / \mathrm{dL}(50-100)$

Urea: $38 \mathrm{mg} / \mathrm{dL}(<50)$

Creatinine: $0.68 \mathrm{mg} / \mathrm{dL}$ (up to 1.20 )

Uric acid: $4.4 \mathrm{mg} / \mathrm{dL}(2.4-6.0)$

Total cholesterol: $165 \mathrm{mg} / \mathrm{dL}(<200)$

HDL cholesterol: $76 \mathrm{mg} / \mathrm{dL}(>59)$
Uma empresária de 53 anos de idade, com queixas constantes de azia, principalmente após as refeições. Ela foi encaminhada à Consulta de Nutrição pelo clínico geral devido a refluxo gastroesofágico, que lhe medicou $\mathrm{o}$ antiácido Maalox.

\section{Avaliação antropométrica}

Peso: $76,7 \mathrm{~kg}$

Altura: $160 \mathrm{~cm}$

IMC: $29,96 \mathrm{~kg} / \mathrm{m} 2$

Circunferência da cintura: $86 \mathrm{~cm}$

Avaliação da composição corporal (TANITA BC-545N) Gordura corporal: $42,8 \%$

Água corporal total: $42,0 \%$

\section{Parâmetros analíticos:}

\section{Hematologia}

Leucócitos: 5,6x109 / L $(4,0-10,0)$

Eritrócitos: 4,9×10 12 L (3,9-5,2)

Hemoglobina: 15,4 g / dL (12,0-16,0)

Hematócrito: 44,4\% (34,7-46,0)

Hemoglobina glicada (A1C): 4,7\% (4,0-6,0)

\section{Bioquímica}

Glicose: 75 mg / dL (50-100)

Ureia: $38 \mathrm{mg} / \mathrm{dL}(<50)$

Creatinina: $0,68 \mathrm{mg} / \mathrm{dL}$ (até 1,20)

Ácido úrico: 4,4 mg / dL (2,4-6,0)

Colesterol total: $165 \mathrm{mg} / \mathrm{dL}(<200)$

Colesterol HDL: 76 mg / dL (> 59) 
LDL cholesterol: $90 \mathrm{mg} / \mathrm{dL}$ (up to 130)

Triglycerides: $47 \mathrm{mg} / \mathrm{dL}$ (up to 150)

Alanine Aminotransferase: $48 \mathrm{U} / \mathrm{L}$ (up to 45)

Aspartate Aminotransferase: $43 \mathrm{U} / \mathrm{L}$ (up to 32 )

Gama Glutamyltransferase: 15 U/L (up to 42 )

Iron: $113 \mu \mathrm{g} / \mathrm{dL}(60-170)$

\section{Endocrinology}

Thyroid Function:

Free T4: $0.9 \mathrm{ng} / \mathrm{dL}(0.7-1.8)$

TSH: $2.3 \mathrm{mUI} / \mathrm{L}(0.4-4.2)$

\section{Anemia}

Ferritin: $56.6 \mu \mathrm{g} / \mathrm{L}(50.0-200.0)$

Folic Acid: $14.4 \mu \mathrm{g} / \mathrm{L}(>4.5)$

Vitamin B12: 639 ng/L (> 200)

\section{Clinical evaluation:}

Medication (symptomatic):

Maalox antacid

Intestinal transit: regular

Eating habits:

Wake up: 7:00 a.m.

Breakfast: black tea and toast with honey and walnuts

During morning: 1 espresso coffee with 1 packet of sugar

Lunch: 12:30 p.m.

Dish: Half a plate of white rice or pasta or 2 potatoes + meat or fish $(140 \mathrm{~g})+$ cooked vegetables $(30 \mathrm{~g})$

Drink red wine $(250 \mathrm{ml})$

After lunch: 1 espresso coffee with 1 packet of sugar

During afternoon:1 orange

Dinner: 7:30 p.m.

Identical to lunch

Between dinner and bedtime: 2 oatmeal biscuits

Water consumed: about 2 L per day

Environment, behavior and social:

Sedentary and without will power to initiate physical activity. She has the habit of going out for dinner two to three times a week and, according with her opinion, she usually eats a lot, feeling badly (heartburn) during the night and having difficulty sleeping. She has difficulty eating every three hours because of her work. She has the habit of drinking coffee after meals and in the morning. She does not notice which foods cause her heartburn.
Colesterol LDL: $90 \mathrm{mg} / \mathrm{dL}$ (até 130)

Triglicerídeos: $47 \mathrm{mg} / \mathrm{dL}$ (até 150)

Alanina aminotransferase: $48 \mathrm{U} / \mathrm{L}$ (até 45)

Aspartato Aminotransferase: $43 \mathrm{U} / \mathrm{L}$ (até 32)

Gama Glutamiltransferase: 15 U / L (até 42)

Ferro: $113 \mu \mathrm{g} / \mathrm{dL}(60-170)$

\section{Endocrinologia}

Função da tiróide:

T4 livre: 0,9 ng / dL $(0,7-1,8)$

TSH: 2,3 mUI / L $(0,4-4,2)$

Anemia

Ferritina: 56,6 $\mu \mathrm{g} / \mathrm{L}(50,0-200,0)$

Ácido fólico: $14,4 \mu \mathrm{g} / \mathrm{L}(>4.5)$

Vitamina B12: $639 \mathrm{ng} / \mathrm{L}(>200)$

\section{Avaliação clínica:}

Medicação (sintomática):

Antiácido Maalox

Trânsito intestinal: regular

Hábitos alimentares:

Acordar: 7:00

Pequeno-almoço: chá preto e torradas com mel e nozes

Durante a manhã: 1 café expresso com 1 pacote de açúcar

Almoço: 12:30

Prato: Meio prato de arroz branco ou massa ou 2 batatas + carne ou peixe $(140 \mathrm{~g})+$ legumes cozidos $(30 \mathrm{~g})$

Bebe vinho tinto $(250 \mathrm{ml})$

Após o almoço: 1 café expresso com 1 pacote de açúcar

Durante a tarde: 1 laranja

Jantar: 19:30

Idêntico ao almoço

Entre o jantar e a hora de dormir: 2 biscoitos de aveia Água consumida: cerca de $2 \mathrm{~L}$ por dia

Ambiente, comportamento e social:

Sedentário e sem força de vontade para iniciar a actividade física. Ela tem o hábito de sair para jantar duas a três vezes por semana e, de acordo com a sua opinião, geralmente come muito, sentindo-se mal (azia) durante a noite e tem dificuldade em dormir. Ela tem dificuldade em comer a cada três horas por causa do trabalho. Ela tem o hábito de tomar café após as refeições e pela manhã. Ela não percebe quais os alimentos que lhe causam azia. 
Questions:

1. What is gastroesophageal reflux?

2. What care to take

3. What foods should be avoided?

4. What are the main symptoms?

5. What are the associated complications?

6. How serious is gastroesophageal reflux?

Answers:

1. Gastroesophageal reflux can be defined as symptoms or complications resulting from the reflux of gastric contents into the esophagus or beyond, into the oral cavity (including larynx) or lung (1). It is caused by the malfunctioning of a kind of valve, specifically, the lower esophageal sphincter (LES), which opens for food to pass from the esophagus to the stomach and then closes to retain what has been ingested as well as gastric juices (2).

2. Eat at the latest three hours following the last meal; Reduce the volume of food especially at night; Reduce the number of coffees; Avoid black tea and alcohol. Decrease the consumption of beverages during the meal. Wait for at least half an hour before going to bed. The pressure on the stomach caused by excess weight also facilitates the onset of reflux $(1,2)$. These dietary changes are intended to help reduce the need for medication. The antacid Maalox side effects that may occur in case of prolonged use or at high doses are the phosphorus depletion. If the patient presents chronic renal failure there is a risk of encephalopathy due to aluminum and intoxication by magnesium $(3,4)$.

3. Avoid black tea and alcohol, chocolate, and acidic foods such as broccoli, cucumber, tomato, and spicy foods. The number of coffees should be reduced $(2,5)$.

4. Cough, heartburn, acid regurgitation, and dysphagia $(1,5,6)$.

5. Erosive esophagitis, stricture, Barrett's esophagus, hiatal hernia, and extraesophageal symptoms $(7,8,9)$.

6 . The lack of prevention can lead to the exacerbation of symptoms with the origination of other complications. One factor that exacerbates the symptoms is weight gain and having a high body mass index (BMI) $(2,7,8)$.
Questões:

1. O que é refluxo gastroesofágico?

2. Que cuidados tomar?

3. Quais os alimentos que devem ser evitados?

4. Quais são os principais sintomas?

5. Quais são as complicações associadas?

6. Qual a gravidade do refluxo gastroesofágico?

Respostas:

1. O refluxo gastroesofágico pode ser definido como sintomas ou complicações resultantes do refluxo do conteúdo gástrico no esófago ou mais além, na cavidade oral (incluindo laringe) ou pulmão (1). É causado pelo mau funcionamento de uma espécie de válvula, chamada esfíncter esofágico inferior (eei): abre a passagem do alimento do esôfago para o estômago e depois fecha para reter o que foi ingerido e também os sucos gástricos (2).

2. Comer o mais tardar três horas após a última refeição; Reduzir o volume de alimentos, especialmente à noite; Reduzir o número de cafés; Evitar chá preto e álcool. Diminuir o consumo de bebidas durante a refeição. Aguardar algum tempo antes de ir para a cama, de pelo menos meia hora. A pressão no estômago causada pelo excesso de peso também facilita o aparecimento do refluxo $(1,2)$. Estas mudanças na dieta visam ajudar a reduzir a necessidade de medicação.

Os efeitos secundários do antiácido Maalox que podem ocorrer em caso de uso prolongado ou em altas doses são a depleção fosforada. Se o paciente apresentar insuficiência renal crónica, existe o risco de encefalopatia devido ao alumínio e de intoxicação pelo magnésio $(3,4)$.

3. Evitar chá preto e álcool, chocolate, alimentos ácidos como brócolos, pepino, tomate, alimentos condimentados e reduzir o número de cafés $(2,5)$.

4. Tosse, azia, regurgitação ácida e disfagia $(1,5,6)$.

5. Esofagite erosiva, estenose, esófago de Barrett, hérnia hiatal e sintomas extraesofágicos $(7,8,9)$.

6. A falta de prevenção pode levar à exacerbação dos sintomas com a origem de outras complicações. Um factor que agrava os sintomas é o ganho de peso e o elevado índice de massa corporal (IMC) $(2,7,8)$. 


\section{References / Referências}

1. Roark, R., Sydor, M., Chatila, A. T., Umar, S., De La Guerra, R., Bilal, M., \& Guturu, P. (2019). Management of gastroesophageal reflux disease. Disease-a-Month, In Press.

2. Ness-Jensen, E., Hveem, K., El-Serag, H., \& Lagergren, J. (2016). Lifestyle intervention in gastroesophageal reflux disease. Clinical gastroenterology and hepatology, 14(2), 175-182.

3. Van Zyl, M. (2011). The effects of drugs on nutrition. South African Journal of Clinical Nutrition, 24(3), S38-S41.

4. Onyango, T. O., Mburu, D. N., Ngugi, M. P., Kamau, J. K., \& Juma, K. K. (2017). Effects of Maalox Plus ${ }^{\circledR}$ Antacid and PureCal ${ }^{\circledR}$ Calcium Supplements on Haematological and Biochemical Parameters of Rats Subjected to Alcohol Intoxication. Journal of Alcoholism \& Drug Dependence, 5(265), 2.

5. Richter, J. E., \& Rubenstein, J. H. (2018). Presentation and epidemiology of gastroesophageal reflux disease. Gastroenterology, 154(2), 267-276.

6. Herregods, T. V. K., Bredenoord, A. J., \& Smout, A. J. P. M. (2015). Pathophysiology of gastroesophageal reflux disease: new understanding in a new era. Neurogastroenterology \& Motility, 27(9), 1202-1213.

7. Katz, P. O., Gerson, L. B., \& Vela, M. F. (2013). Guidelines for the diagnosis and management of gastroesophageal reflux disease. The American journal of gastroenterology, 108(3), 308 .

8. Moore, M., Afaneh, C., Benhuri, D., Antonacci, C., Abelson, J., \& Zarnegar, R. (2016). Gastroesophageal reflux disease: a review of surgical decision making. World journal of gastrointestinal surgery, 8(1), 77.

9. Tan, V. P. Y., Wong, B. C., Wong, W. M., Leung, W. K., Tong, D., Yuen, M. F., \& Fass, R. (2016). Gastroesophageal Reflux Disease. Journal of Clinical Gastroenterology, 50(1), e1-e7. 